UNITED STATES DEPARTMENT OF THE INTERIOR

\author{
GEOLOGICAL SURVEY
}

\title{
Complete Bouguer gravity anomaly map for an area near Raleigh, North Carolina, and digital principal \\ facts on diskette for $\mathbf{4 2 8}$ gravity stations
}

by

David L. Daniels ${ }^{1}$

Open-File Report 92-540

This report is preliminary and has not been reviewed for conformity with U.S. Geological Survey editorial standards (or with the North American Stratigraphic Code). Any use of trade, product, or firm names is for descriptive purposes only and does not imply endorsement by the U.S. Government.

1 U.S. Geological Survey, Reston, Virginia 


\section{TABLE OF CONTENTS}

INTRODUCTION $\ldots \ldots \ldots \ldots \ldots \ldots \ldots \ldots \ldots \ldots \ldots \ldots \ldots$

PRIOR GRAVITY SURVEYS $\ldots \ldots \ldots \ldots \ldots \ldots \ldots \ldots \ldots \ldots \ldots$

DATA COLLECTION AND REDUCTION $\ldots \ldots \ldots \ldots \ldots \ldots \ldots \ldots$

THE COMPLETE BOUGUER GRAVITY ANOMALY MAP $\ldots \ldots \ldots \ldots \ldots \ldots$

LIST OF FIGURES $\ldots \ldots \ldots \ldots \ldots \ldots \ldots \ldots \ldots \ldots \ldots \ldots$

TABLE 1 (sample of gravity principal facts) $\ldots \ldots \ldots \ldots \ldots \ldots$

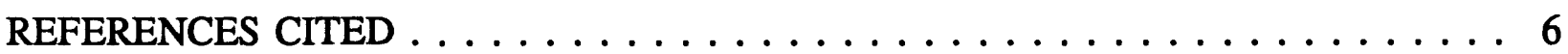

DIGITAL DATA FILE OF GRAVITY PRINCIPAL FACTS

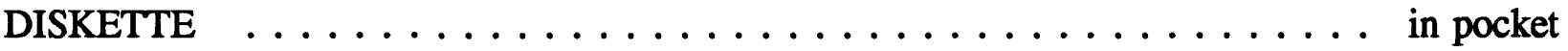




\title{
Complete Bouguer gravity anomaly map for an area near Raleigh, North Carolina and digital principal facts on diskette for $\mathbf{4 2 8}$ gravity stations
}

by

\author{
David L. Daniels
}

\section{INTRODUCTION}

A complete Bouguer gravity anomaly map was prepared for eight $7.5^{\prime}$ quadrangles based on 428 gravity stations collected during 1990 within the Raleigh 30' x 60' quadrangle in an area just south of Raleigh, North Carolina (see figures 1 and 2). The work was done in support of the U.S. Geological Survey COGEOMAP Program, which in this case was a cooperative effort with the Geological Survey of North Carolina. The study area was selected because an examination of the national digital gravity data base, maintained by the U.S. Defense Mapping Agency, and a compilation of that data by Black (1987) revealed a lack of previous gravity measurements. The principal facts for the gravity stations are supplied as an ASCII file on a 5.25 inch floppy disk (DOS based computers, $360 \mathrm{~KB}$ double density diskette).

\section{PRIOR GRAVITY SURVEYS}

The gravity file maintained by the Defense Mapping Agency was searched for data within or near the study area. The largest data set found is a gravity survey of the Deep River basin made in 1975 by D.M. Best (unpublished). This survey crosses the northwest part of the study area in the Apex quadrangle (Figure 2). New stations were placed in the Apex quadrangle to complement Best's survey. A second survey by the Air Force Geophysics Laboratory (AFGL) was added to the Defense Mapping Agency file after the current survey was completed. The AFGL survey consists of 87 stations in a tight cluster in the Garner 7.5 minute quadrangle (Figure 2). Stephens (1988) made a detailed gravity survey of most of the northern half of the Raleigh 30' x 60' quadrangle to study the structure of the Rolesville granite. His survey adjoins the current survey to the north.

\section{DATA COLLECTION AND REDUCTION}

All of the measured stations were tied to a new base station established for this survey, located in Cary, North Carolina near the interchange of Interstate 40 and US Routes 1 and 64 (Figures 3 and 4). The observed gravity for this base was obtained by a tie to a now inaccessible base station on the IGSN71 net (Raleigh K; ISGN71 value of 979,787.26 mGals) at the Raleigh-Durham Airport (Morelli and others, 1974, p. 45). All measurements were made with a Lacoste and Romberg gravity meter G-159. Elevations marked on the 7.5 
minute quadrangle 1:24,000 scale topographic maps published by the U.S. Geological Survey (UGSG) are the source of elevation control. Bench marks and "useful elevations" were used for $9 \%$ of the stations, spot elevations at road intersections for $85 \%$ of the stations, and elevations interpolated from contours for the remaining 6\%. The term "useful elevations" includes unlabeled marks (typically a square) chiseled on concrete or rock outcrops during the surveying for a line of bench marks.

After plotting station locations on 1:24,000 scale USGS topographic maps, latitude and longitude were determined using a digitizing tablet under the control of computer program GSDIG, version 2.0 (Selner and others, 1988).

Observed gravity measurements were corrected for computed earth-tide and linear meter-drift. Bouguer gravity anomaly values were computed using the 1967 gravity formula (International Association of Geodesy, 1971) with a reduction density of $2.67 \mathrm{~g} / \mathrm{cm}^{3}$. Terrain corrections were made by computer (Plouff, 1977) for the region extending radially from 0.895 to $166.7 \mathrm{~km}$ by utilizing digital terrain data. The computed terrain corrections use mean-elevation data in the form of a terrain grid at intervals of 30 seconds in latitude and longitude for corrections from 0 to $5 \mathrm{~km}$, a 1-minute terrain grid for corrections from 5 to 21 $\mathrm{km}$, and a 3-minute terrain grid for corrections from 21 to $166.7 \mathrm{~km}$. A correction for the Earth's curvature is also applied. Reduction procedures are described in greater detail by Cordell and others (1982).

The largest source of error in the Bouguer anomalies lies in the elevation uncertainty. About half of the bench marks used as stations were found to be in good condition, which imparts the highest level of accuracy (about \pm 0.5 feet). Other bench marks used as reference elevations were not actually observed, usually because they were covered by thick vegetation or by soil. These were still useful for elevation control, because in this region of gentle topography, precise bench mark descriptions of the locations permit reasonably accurate recovery of the location. These were considered to carry the accuracy of spot elevations. The road intersection or "spot" elevations at which most of the stations were placed have an accuracy of $\pm 1 / 3$ the contour interval (USGS, National Map Accuracy Standards, unpublished) of the topographic maps (contour interval $=10$ feet). The least accurate type of reference elevation is obtained by interpolation of contours and was used only where more accurate control was absent. These reference elevations have an accuracy of $\pm 1 / 2$ of the contour interval of the maps. The elevation uncertainties of the spot elevations and interpolated elevations are therefore about \pm 3 and \pm 5 feet respectively and produce a corresponding uncertainty in the combined free air and Bouguer correction of \pm 0.18 to 0.3 $\mathrm{mGal}$. Table 1 contains a sample of the principal facts listed in the file on the diskette. The 3 letter station-code indicates the quadrangle name.

The distribution of the stations is shown in Figure 5 and the contoured complete Bouguer anomaly values are shown in Figure 6. The few stations in the Apex and Clayton quadrangles (Figure 2) do not adequately define the contours in these quadrangles. In Figure 7 gravity contours are shown superimposed upon a geologic map of the area modified from Farrar (1985). 


\section{THE COMPLETE BOUGUER GRAVITY ANOMALY MAP}

The dominant feature of the Bouguer map, in terms of amplitude and wavelength, is the low in the northeast quadrant with the minimum $(-40 \mathrm{mGals})$ in the Clayton quadrangle. This low correlates with the southern end of the Rolesville granite pluton (unit $\mathrm{Rg},+$ pattern, Figure 7). Although there are only 7 stations in the Clayton quadrangle, the distribution is sufficient to show that the minimum lies on the east side of the pluton, $5 \mathrm{~km}$ from the east contact (North Carolina Geological Survey, 1985; Farrar, 1985) and $20 \mathrm{~km}$ from the western contact (Figure 7). This same position of the gravity minimum in the adjacent quadrangles to the north was noted by Stephens (1988). He concluded that both eastern and western contacts of the pluton dip to the east and the minimum marks the position of the greatest vertical extent of the pluton rather than resulting from variations in composition, because measured densities of the granite show only a narrow range.

Highest gravity values form an arc with the maximum $(+1 \mathrm{mGal})$ in the Angier quadrangle. The arcuate gravity high shows a close correspondence with an arcuate aeromagnetic high (Zietz and others, 1984), which indicates a mafic source. The arcuate gravity anomaly extends eastward through the Edmondson quadrangle ending in the Powhatan quadrangle where the gravity maxima correlate with amphibolite of the Stanhope Formation (unit STa, dark pattern, Figure 7). The maximum in the Angier quadrangle coincides with the contact between this amphibolite and the muscovite-biotite schist-felsic gneiss unit of the Smithfield Formation (unit SMsg, Figure 7). If the source of the high in the Angier quadrangle is the amphibolite, then the position of the anomaly suggests that the amphibolite dips westward beneath the Smithfield Formation. 


\section{LIST OF FIGURES}

Figure 1 Map showing North Carolina and the location of the Raleigh 30' x 60' quadrangle.

Figure 2 Map of the Raleigh 30' x 60' quadrangle showing the locations of the quadrangles of the gravity survey.

Figure 3 Road map of the Raleigh area (Top). Rectangle indicates area enlarged in lower map which shows the location of the Days Inn gravity base established for the survey. The location of the base is shown in greater detail in Figure 4.

Figure 4 Map of the parking area at the rear of the Days Inn in Cary, NC (see Figure 3 ) showing the location of the gravity base used for the survey. Base is on raised concrete adjacent to fire hydrant. Geographic coordinates $=-7^{\circ} 44.69^{\prime} \mathrm{W}, 35^{\circ} 45.82^{\prime} \mathrm{N}$; elevation $=$ 490 feet; observed gravity $=979,763.00 \mathrm{mGals}$ (IGSN71) based on tie to gravity base Raleigh K (Morelli and others, 1974) which is located in Terminal B (currently inaccessible) at Raleigh-Durham Airport.

Figure 5 Map of the study area showing distribution of the 428 gravity stations (+ symbols).

Figure 6 Complete Bouguer gravity anomaly map of the study area. Contour interval is $1 \mathrm{mGal}$. Hachures point toward lower values.

Figure 7 Complete Bouguer gravity anomaly contours (from figure 6) superimposed upon geologic map (units and symbols from Farrar (1985). Coastal Plain units omitted. 
Table 1 Sample of the gravity principal facts to be found on the diskette. The three letter part of the station id refers to the 7.5 minute quadrangle in North Carolina as follows:

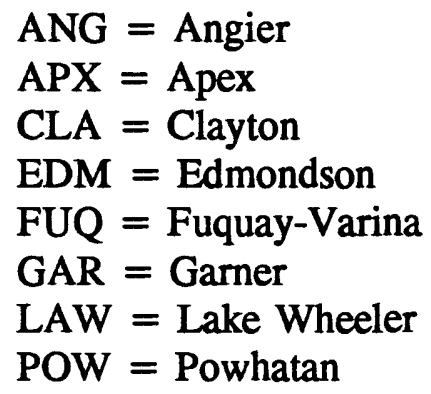

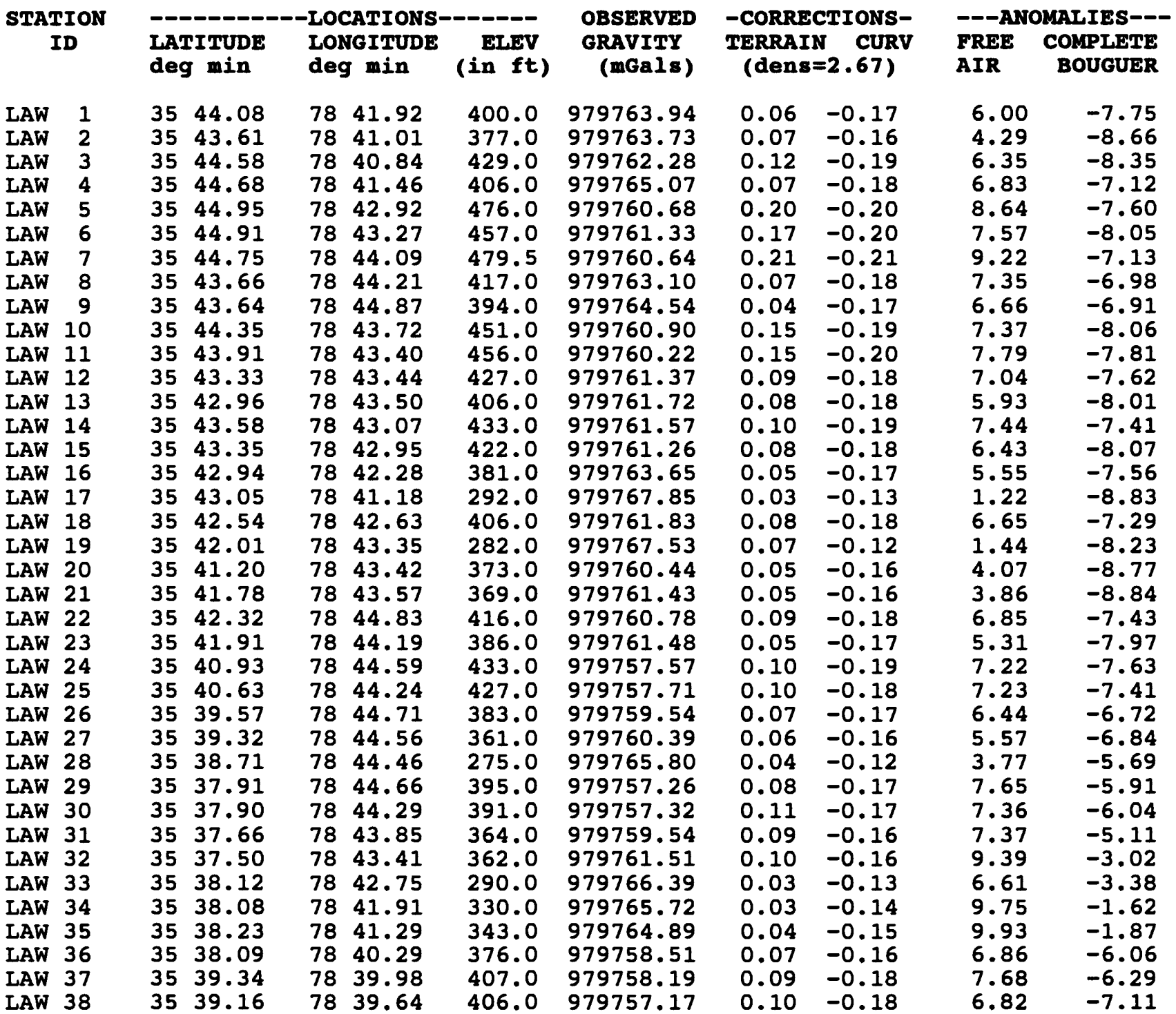




\section{REFERENCES CITED}

Black, W.W., 1987, Simple Bouguer and residual Bouguer gravity maps of North Carolina: North Carolina Department of Natural Resources and Community Development, Geological Survey Section Open-File 87-1 and 87-2, 2 maps, scale 1:500,000, text 3p.

Cordell, Lindrith, Keller, G.R., and Hildenbrand, T.G., 1982, Complete Bouguer gravity anomaly map of the Rio Grande Rift, Colorado, New Mexico, and Texas: U.S. Geological Survey Geophysical Investigations Map GP-949, scale 1:1,000,000.

Farrar, S.S., 1985, Tectonic evolution of the easternmost Piedmont, North Carolina: Geological Society of America Bulletin, v. 96, p. 362-380.

International Association of Geodesy, 1971, Geodetic Reference System 1967: Paris, International Association of Geodesy Special Publication, no. 3, 116p.

Morelli, C., Gantar, C., Honkasalo, T., McConnell, R.K., Tanner, J.G., Szabo, B., Uotila, U., and Whalen, C.T., 1974, The International gravity standardization net 1971 (I.G.S.N.71): Paris, Bureau Central de L'Association Internationale de Geodesie, Publication Speciale No. 4, 194p.

North Carolina Geological Survey,1985, Geologic Map of North Carolina: North Carolina Department of Natural Resources and Community Development, Geological Survey Section, scale 1:500,000.

Plouff, Donald, 1977, Preliminary documentation for a FORTRAN program to compute gravity terrain corrections based on topography digitized on a geographic grid: U.S. Geological Survey Open-File Report 77-535, 45p.

Selner, G.I., Smith, C.L., and Taylor, R.B., 1988, GSDIG Version 2.0, a program to determine latitude/longitude coordinates, and GSDXY Version 1.0 a counterpart program to determine $\mathrm{X}, \mathrm{Y}$ coordinates, using a microcomputer (IBM PC or compatible) and digitizer: U.S. Geological Survey Open File Report 88-428A,B, 29p., 1 diskette.

Stephens, E.H., 1988, Structure of the Rolesville batholith and adjacent metamorphic terranes in the east-central Piedmont, North Carolina: a geophysical perspective: North Carolina State University, Department of Marine, Earth, and Atmospheric Sciences, Raleigh, North Carolina, Masters Thesis, $166 \mathrm{p}$.

Zietz, Isidore, Riggle, F.E., and Gilbert, F.P., 1984, Aeromagnetic map of North Carolina: U.S. Geological Survey Geophysical Investigations Map GP-957, scale 1:500,000. 


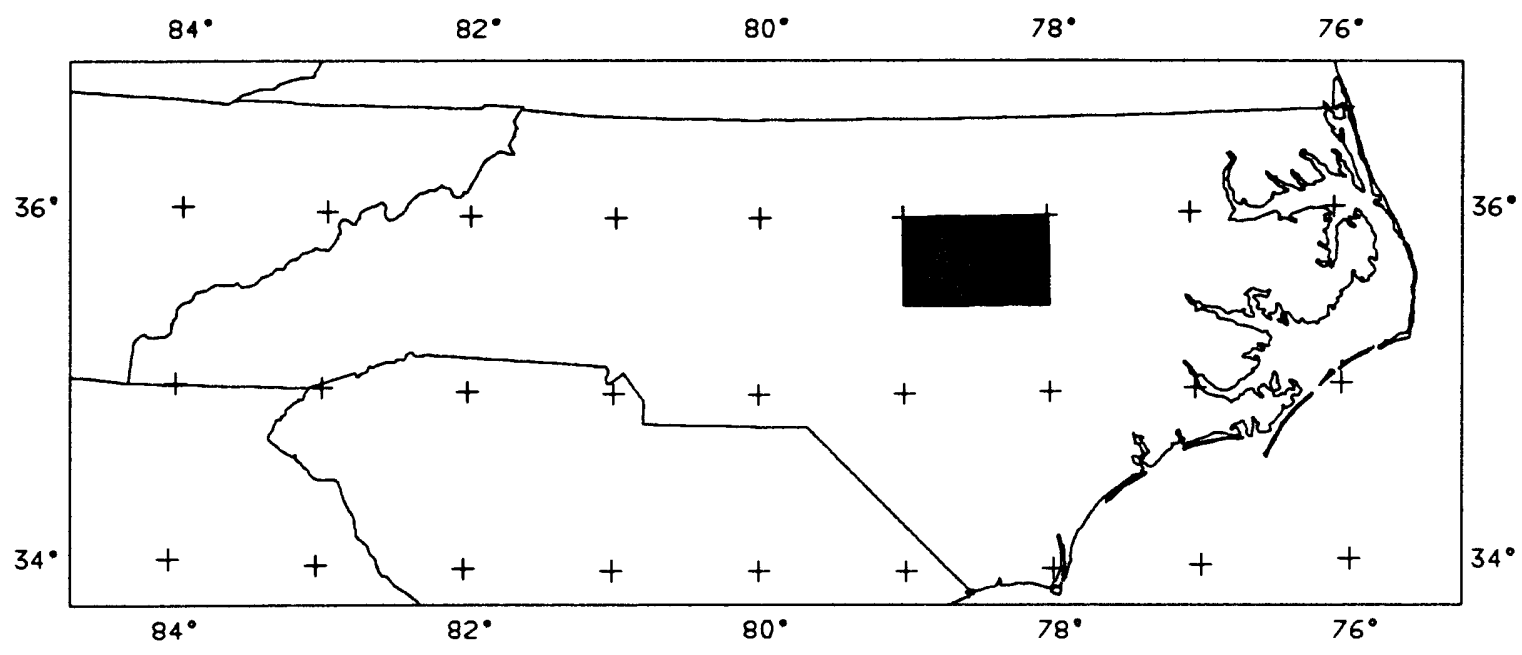

Figure 1 Map showing North Carolina and the location of the Raleigh 30' x 60' quadrangle.

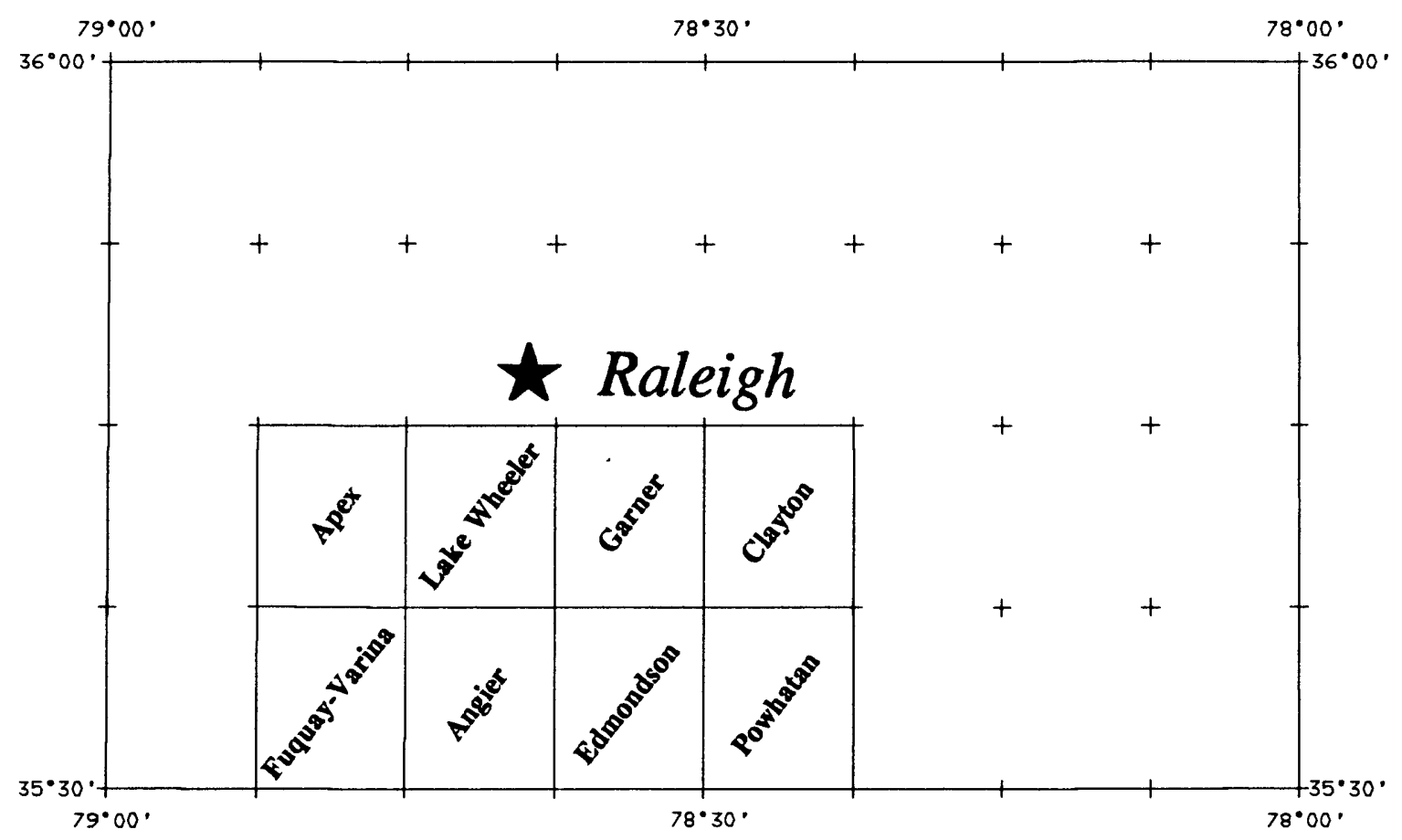

Figure 2 Map of the Raleigh 30' x 60' quadrangle showing the location of the quadrangles of the gravity survey. 

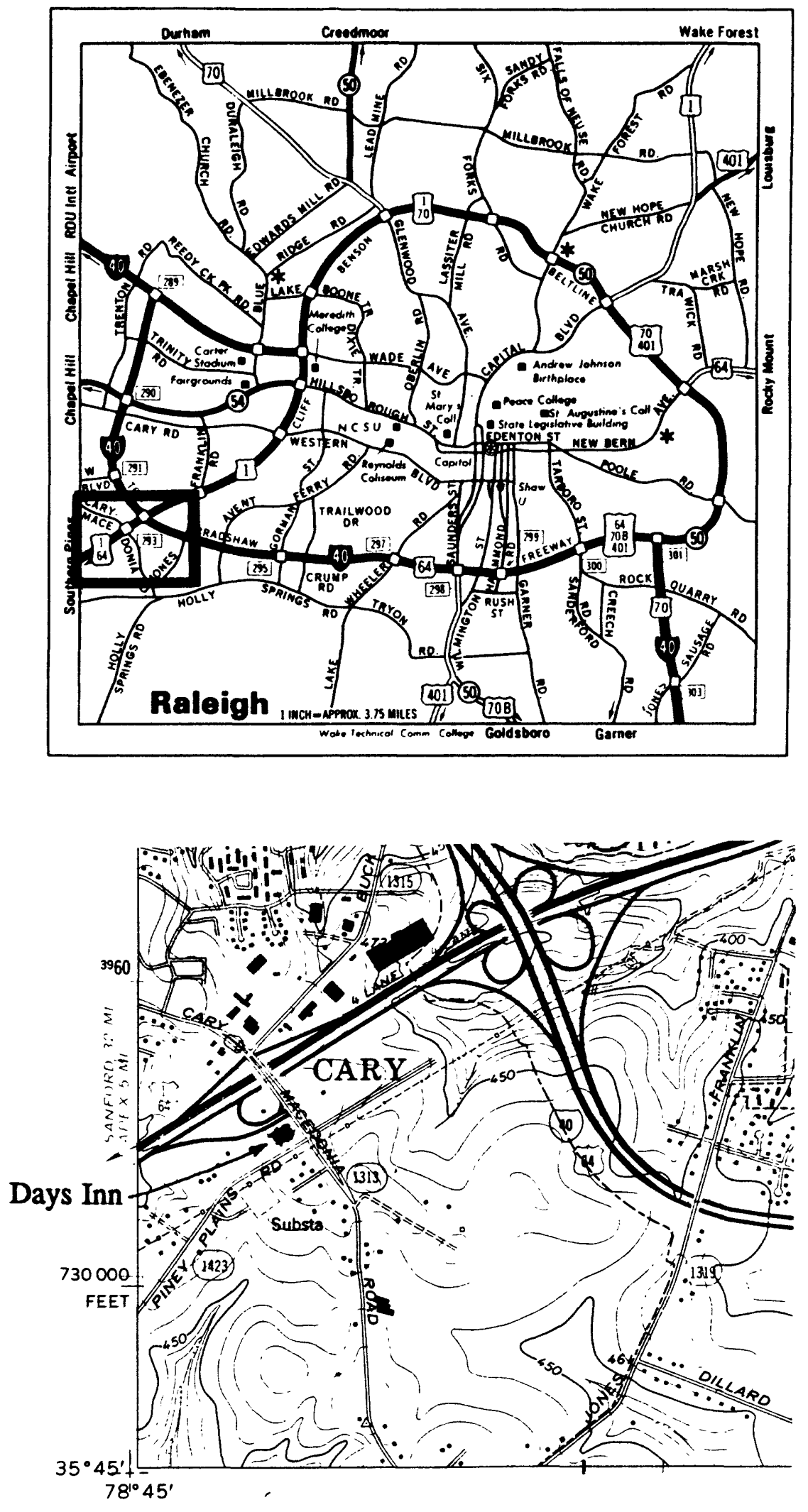

Figure 3 Road map of the Raleigh area (Top). Rectangle indicates area enlarged in lower map which shows the location of the Days Inn gravity base established for the survey. The location of the base is shown in greater detail in Figure 4. 


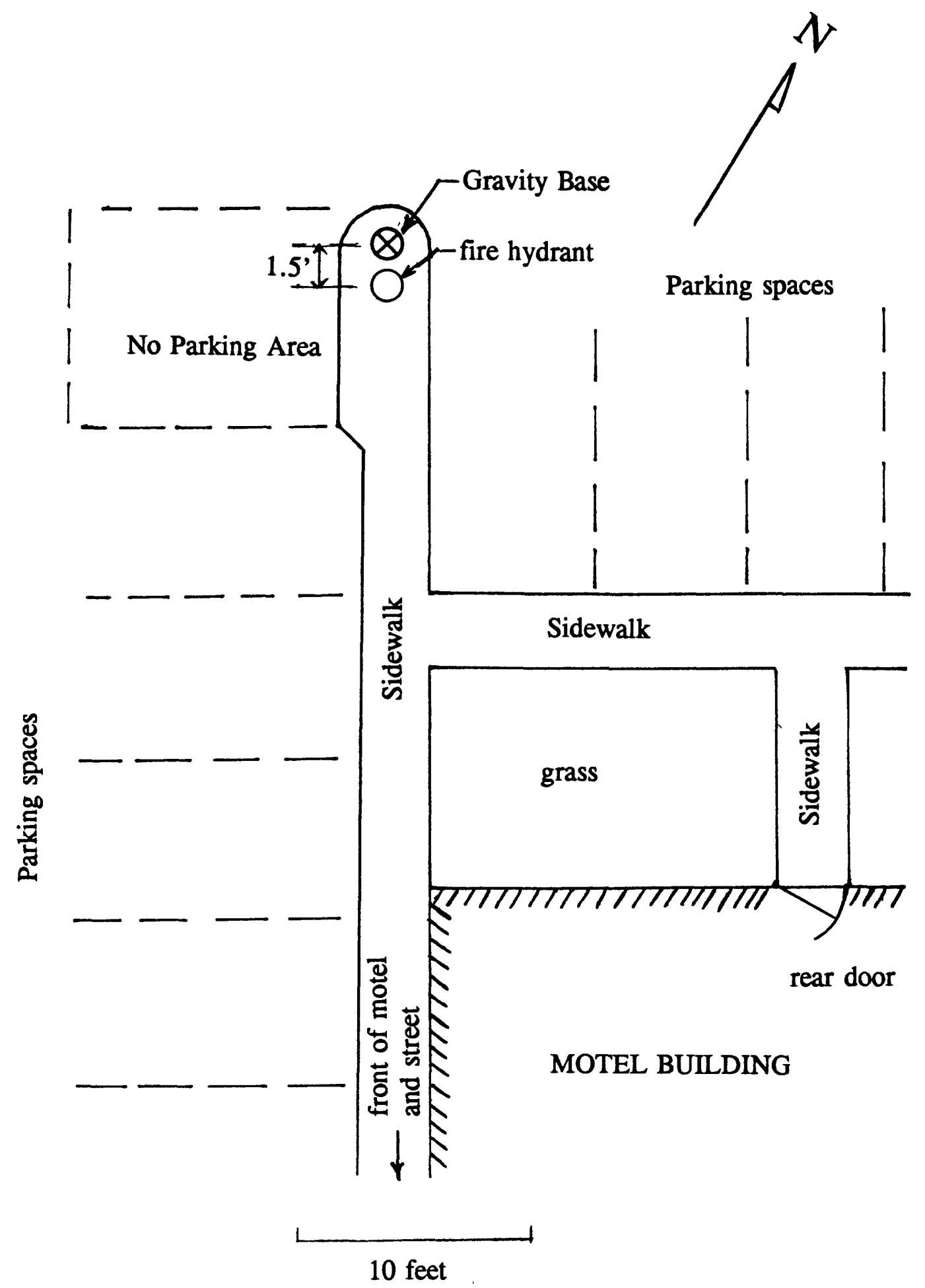

Figure 4 Map of the parking area at the rear of the Days Inn in Cary, NC (see Figure 3 ) showing the location of the gravity base used for the survey. Base is on raised concrete adjacent to fire hydrant. Geographic coordinates $=-78^{\circ} 44.69^{\prime} \mathrm{W}, 35^{\circ} 45.82^{\prime} \mathrm{N}$; elevation = 490 feet; observed gravity $=979,763.00 \mathrm{mGals}$ (IGSN71) based on tie to gravity base Raleigh K (Morelli and others, 1974) which is located in Terminal B (currently inaccessible) at Raleigh-Durham Airport. 

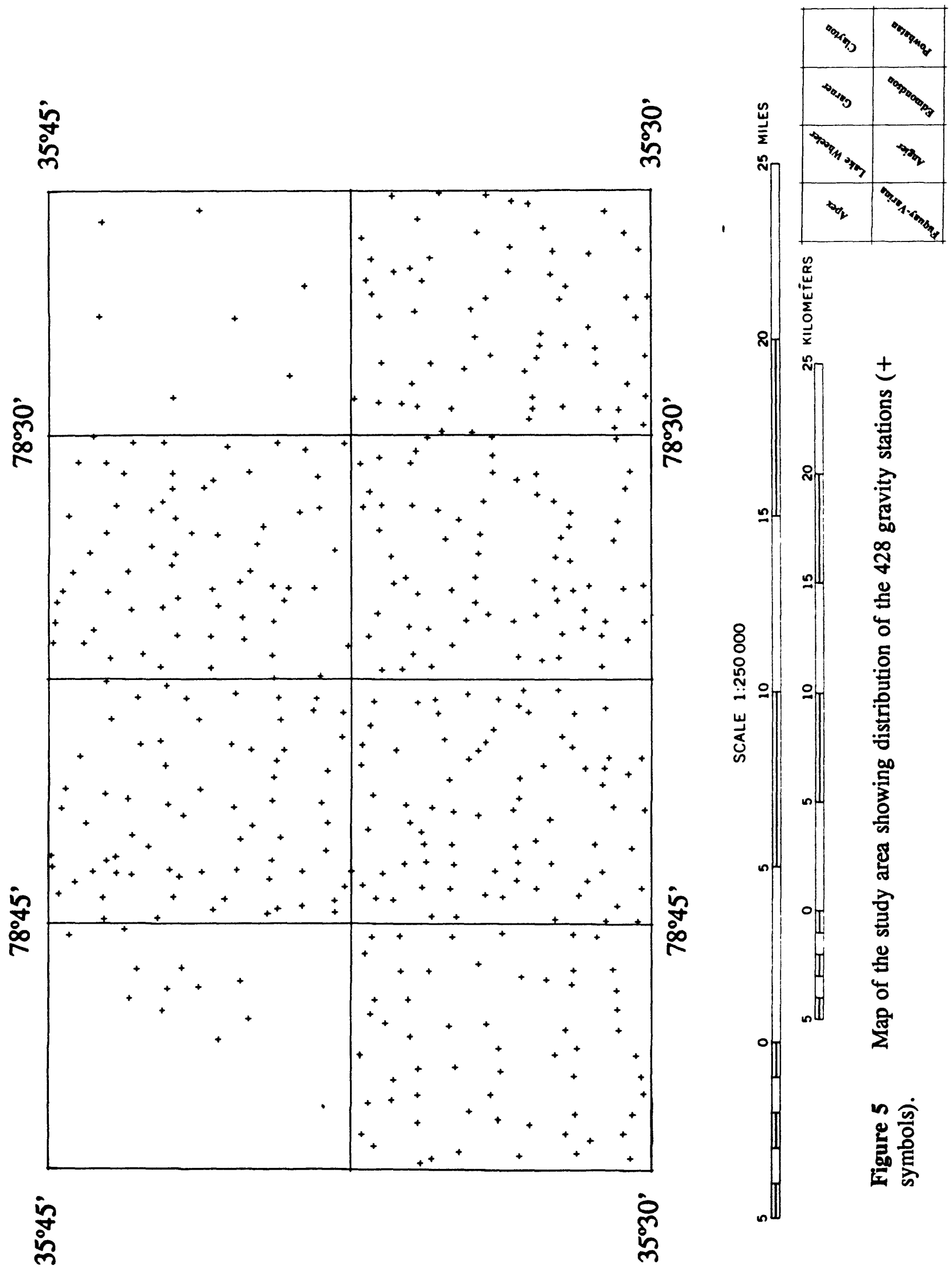

立

n

+

$\simeq$
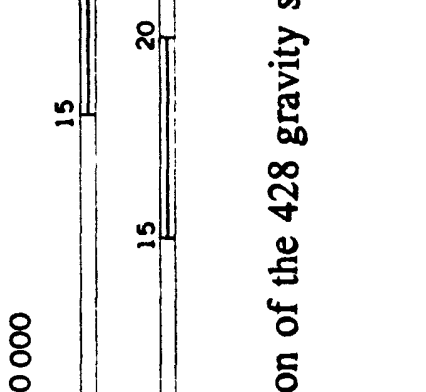

in

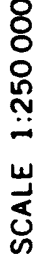

에 에 $\frac{.05}{3}$

(1)

๓

- $\frac{7}{3}$

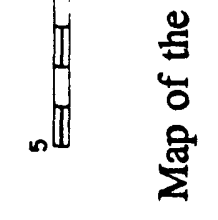

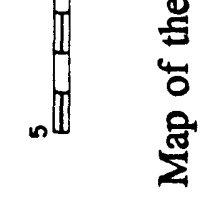

(1)

我客 


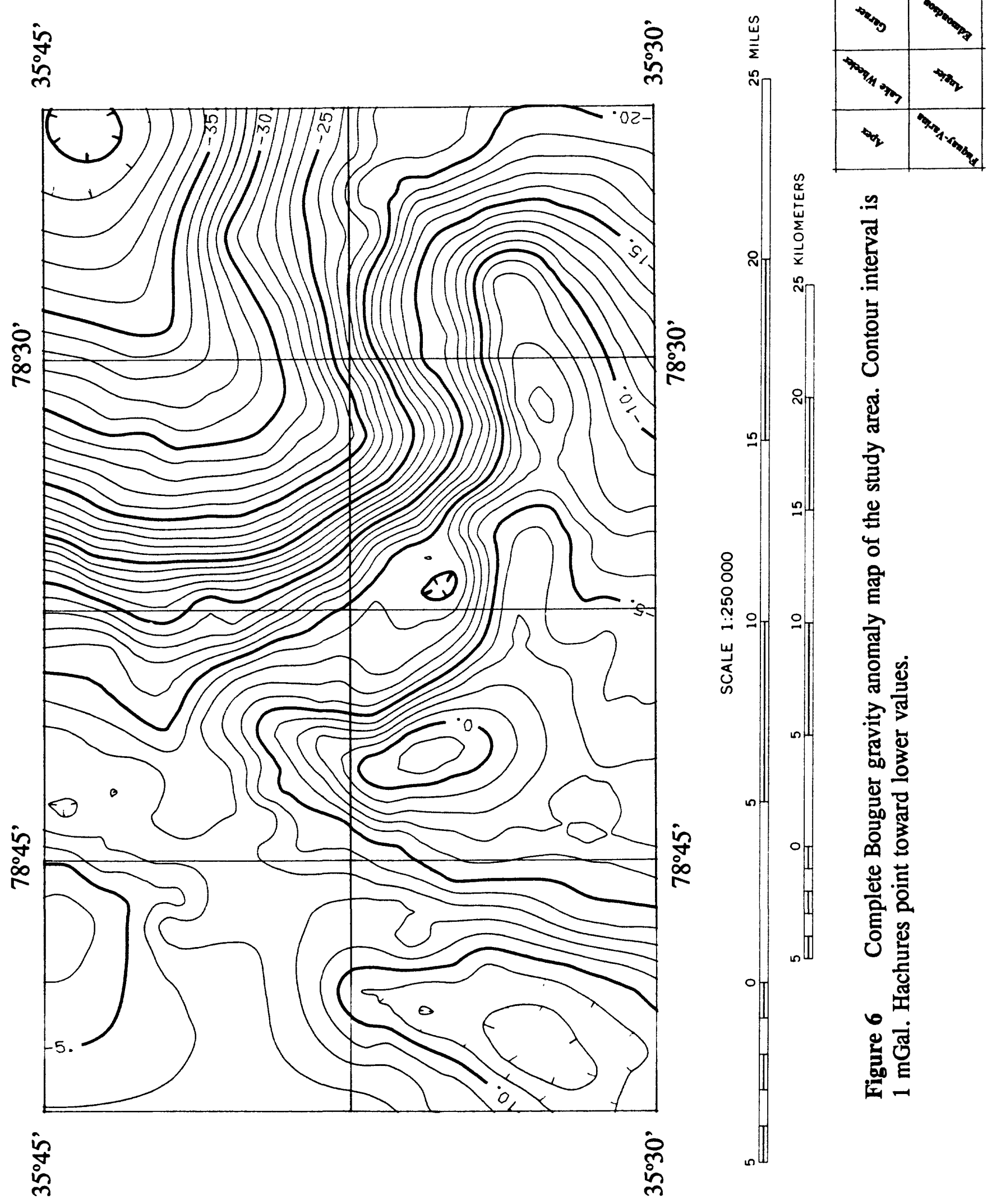


兮

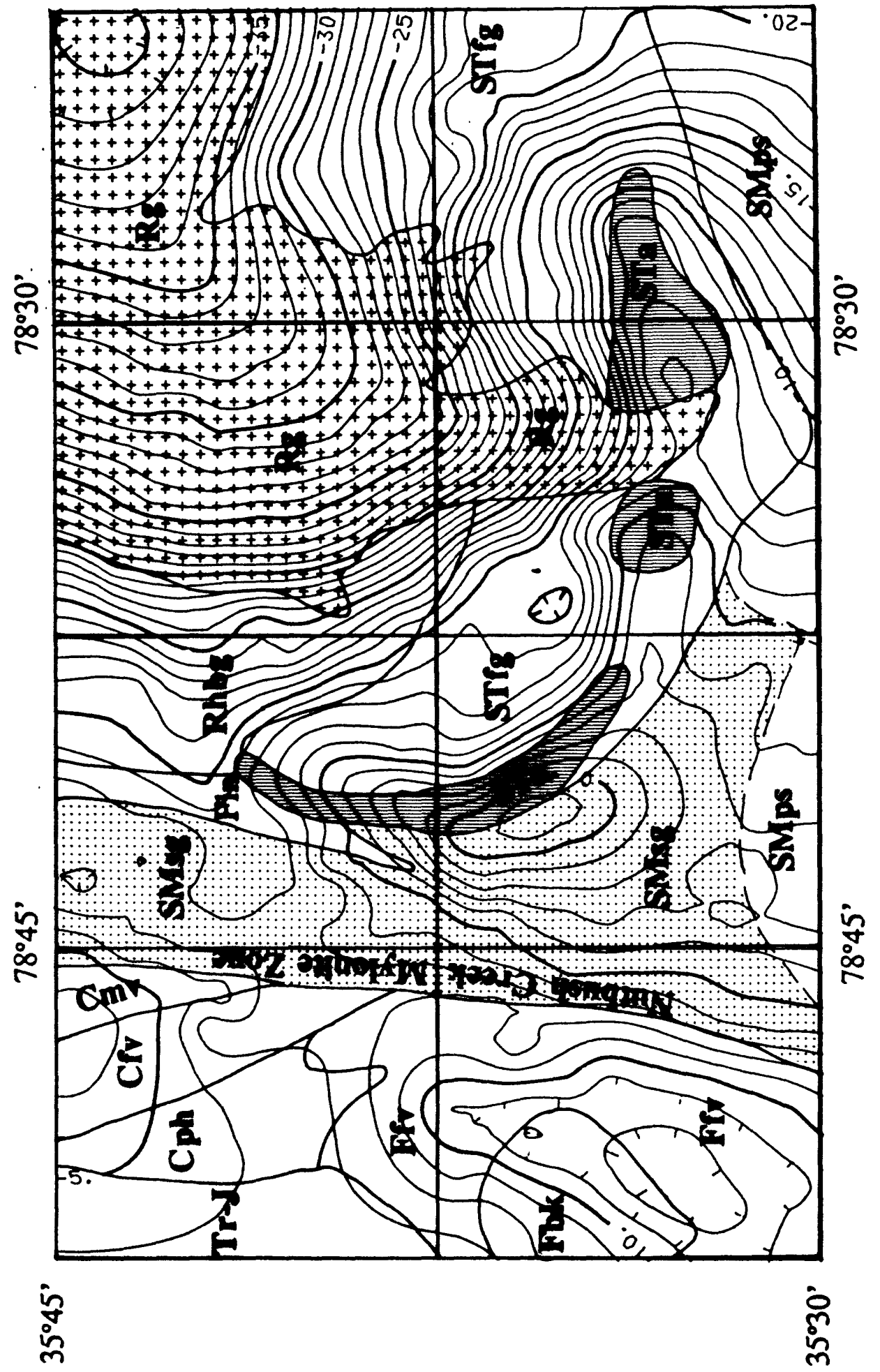

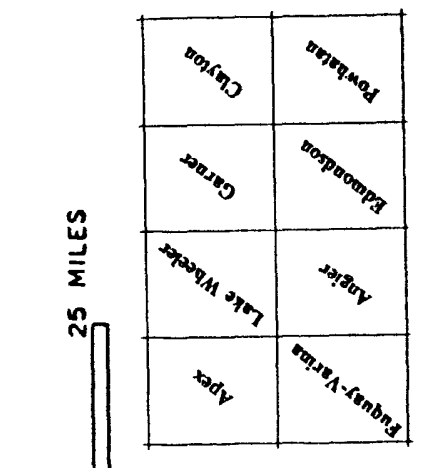

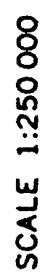

पु

员

氮需

젼

总苋

参

을

의 의 휼

곤

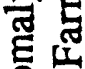

동

론

正

क⿺⿻一⿰冫⿰亅⿱丿丶丶⿱⿰㇒一乂

实

웅 을

苗

品

号

응 응

n

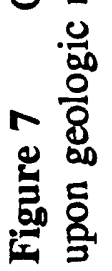




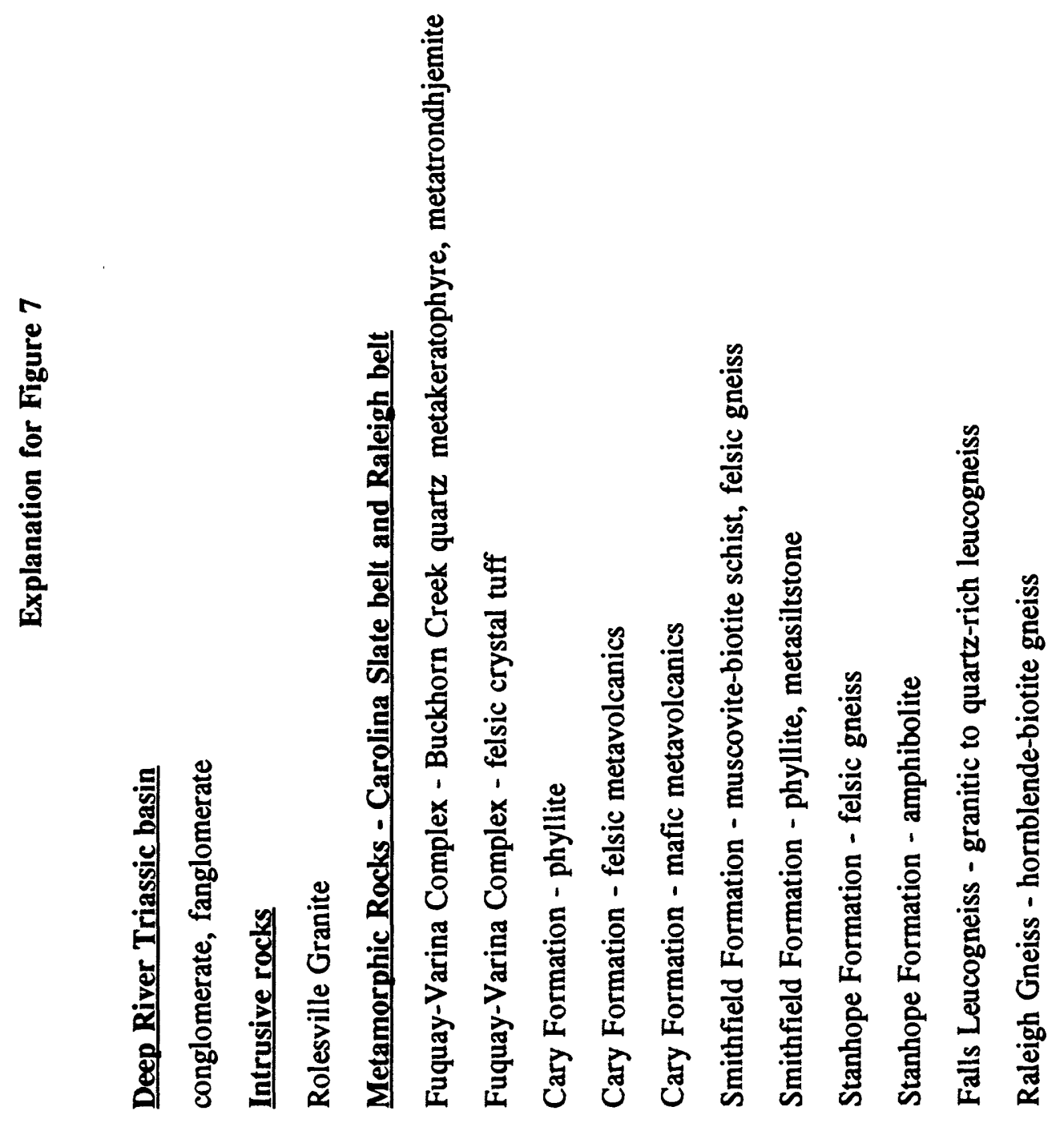

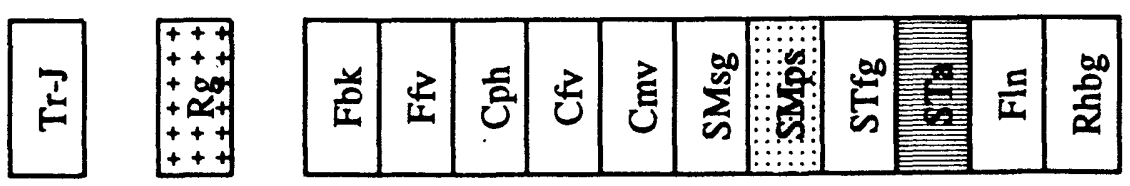

